\title{
The Conflict Minerals Rule
}

\author{
Private Alternatives?
}

A.L. Vytopil*

\section{Introduction}

In the wake of the financial crisis in the United States, a new act was adopted that, inter alia, aims to 'promote the financial stability of the United States by improving accountability and transparency in the financial system'. 'The Dodd Frank Wall Street Reform and Customer Protection Act (DFA) not only seeks to improve accountability for financial institutions, but also includes two sections that - unlike the rest of the DFA - are primarily aimed at increasing transparency in respect of the social and ethical responsibility of companies. Section 1502 DFA imposes a duty to disclose certain information on companies that make use of certain 'conflict minerals' originating in the Democratic Republic of the Congo (DRC) and nine adjoining countries; Section 1504 DFA imposes a similar duty in relation to payments made by companies to foreign governments. Following Section 1502 DFA, the Securities and Exchange Commission (SEC) adopted a rule that further specifies those requirements. On 22 August 2012, the SEC issued its final rule in respect of conflict minerals, implementing Section 1502 DFA (the 'Rule'). This is a significant development in light of the increasing debate worldwide on international corporate social responsibility (CSR) in general and the transparency of multinationals more particularly.

This article will explain the background and content of Section 1502 DFA. It will set out what companies must do in order to comply with Section 1502 DFA. Next, it will provide an overview of some of the societal criticism to the Rule and the legal challenge of the Rule with the District Court for the District of Columbia. The subsequent ruling of this Court of 23 July 2013 will also be discussed.

Since this is not the only American legislation in relation to transparency and CSR, the next section will discuss two Californian Acts of legislation in respect of the DFA and transparency in the supply chain.

The final section of this article will look at a number of private regulatory initiatives in place that have aims

* Louise Vytopil, LL.B MA MSc, is a Ph.D.-candidate and assistant-professor at Utrecht University's Molengraaff Institute for Private Law.

1. Dodd-Frank Wall Street Reform and Consumer Protection Act (Enrolled Final Version - HR 4173). similar to Section 1502 DFA. After all, many companies already take action to regulate their behaviour and that of their supply partners. In the course of doing so, companies can improve transparency in their supply chain and perhaps also create binding obligations for their supply partners. The relevant question in this case is then: when are private initiatives such as codes of conduct legally binding?

This article will conclude that when looking at the possibility of adopting and implementing legislation similar to the DFA in Europe, the administrative and practical burden of such legislation will likely not outweigh the possible benefits, also given the amount of self-regulation currently already in place in, for example, the Netherlands and England. One may then wonder to what extent legislation that needs to overcome many imperfections would be a valuable addition to the private-regulation framework currently in place.

\section{Section 1502 of the DFA and the SEC Rule}

On 21 July 2010, the US Congress passed the DFA. Whilst the biggest portion by far of this act relates to the transparency in the US financial system, with the goal of, inter alia, providing more insight into the workings of financial institutions and preventing bailouts of banks at the cost of American taxpayers, two sections are not geared toward financial institutions but rather toward companies in general. These parts fall within the category of 'miscellaneous provisions' that is included at the close of the DFA. They seek to improve transparency in respect of two subjects: the use of so-called 'conflict minerals' (Section 1502) and payments made by companies to governments (Section 1504). Pursuant to Section 1504, a further discussion of which falls outside the scope of this article, publicly traded companies in the extractive industry are required to provide information in respect of payments made by them to either the federal US government or to foreign (decentralized) governments.

Section 1502, on the other hand, imposes certain provisions and disclosure requirements for companies due diligence in respect of certain conflict minerals, in order to identify whether these minerals originated in the DRC or adjoining countries. The goal and purpose of 
this section of the DFA is to diminish the trade in these conflict minerals, which act as a main source for financing the conflict that causes much violence and human rights violations in the DRC and its surrounding countries. Congress has indicated in Section 1502(a) DFA that

It is the sense of the Congress that the exploitation and trade of conflict minerals originating in the Democratic Republic of the Congo is helping to finance conflict characterized by extreme levels of violence in the eastern Democratic Republic of the Congo, particularly sexual- and gender-based violence, and contributing to an emerging humanitarian situation therein, warranting the provisions of section 13(p) of the Securities Exchange Act of 1934, as added by subsection (b).

Section 1502 DFA concerns conflict minerals from the DRC and ten surrounding countries ('Covered Countries'): the Central African Republic, Sudan, Uganda, Rwanda, Burundi, Tanzania, Zambia, Angola, and the Republic of the Congo.

The four 'conflict minerals'2 covered by the DFA are the three T's (tin, produced from casserite ore; tantalum, produced from coltan; and tungsten, produced from wolframite) as well as gold. Other minerals may also be added to the definition if determined by the Secretary of State. Together, the Covered Countries produce as much as up to 15 percent of the world's supply of tantalum and up to 5 percent of the world's tin. The use of these conflict minerals is widespread. They can be found in consumer products such as mobile phones, on/off buttons of electronic devices, jewellery and glass. Conflict minerals are also extensively used in, for instance, the automotive industry, pesticides and sheet metal.

Section 1502 DFA covers those companies that file reports with the SEC under the Exchange Act and that manufacture products for which conflict minerals are 'necessary to the functionality or production'. As such, it covers not only American companies, but also European companies that are listed at the stock exchange in the United States.

Section 1502 DFA requires that companies that make use of potential conflict minerals are to investigate whether those minerals had originated in the Covered Countries or whether they derive from recycled or scrap sources. If the minerals are found to have been newly mined in the Covered Countries, the company must carry out due diligence on the source and chain of custody of those materials.

Pursuant to the Securities and Exchange Act, ${ }^{3}$ the SEC is obligated to provide guidance, through the means of a rule in respect of Section 1502. A detailed, 29-page draft

2. Called such because they are sometimes exploited to finance conflict in the Covered Countries.

3. The DFA has amended the Securities and Exchange Act by adding a new clause, Section 13(p), in accordance with which the SEC must offer guidance in respect of Section 1502 DFA. rule was released by the SEC in December $2010 .^{4}$ In this proposed rule, the SEC offered guidance to companies whose products contain conflict minerals in respect of their due diligence process and reporting requirements. Moreover, it posed a number of questions to the public, for instance, in respect of the way in which to define the term 'necessary to the functionality or production of a product'. After much debate and criticism (most notably from the manufacturing industry), the SEC issued its final rule (the 'Rule') on 22 August 2012, with a final vote of 3-2 in favour of the rule.

The Rule, a 356-page document, sets out what is expected of companies in order for them to meet Section 1502 DFA. In short, the Rule amounts to a three-step process.

First of all, as indicated before, the Rule covers those companies that file reports with the SEC under the Exchange Act, if they 'manufacture or contract to manufacture products for which conflict minerals are necessary to the functionality or production of that product.' If this is the case, the next step for companies is to carry out a 'reasonable country of origin inquiry'. This step means that companies must ascertain that the minerals used either did not originate from the Covered Countries or did not finance (directly or indirectly) armed groups in the Covered Countries.

This due diligence must be carried out on the basis of a nationally or internationally recognized framework if one is available for the specific conflict mineral in question. In the Rule, the SEC mentions that

the OECD's “Due Diligence Guidance for Responsible Supply Chains of Minerals from Conflict-Affected and High-Risk Areas" satisfies our criteria and may be used as a framework for purposes of satisfying the final rule's requirement that an issuer exercise due diligence in determining the source and chain of custody of its conflict minerals. ${ }^{5}$

The company must then file a Specialised Disclosure (SD) form to that extent with the SEC, which provides determinations from the country of origin inquiry and a brief description of the results. If the used minerals do not originate from the covered countries or if the company finds that they derive from recycled or scrap sources, its requirements under Section 1502 DFA ends here. The company may then market their products as 'DRC conflict free'.

If, on the other hand, there is a reasonable risk that the conflict minerals originate from a Covered Country, it must file an additional 'Conflict Minerals Report'. This Report must contain an account of its due diligence efforts, a description of products found not to be conflict-mineral free, the facilities used for the processing of the conflict minerals, the country of origin of the conflict minerals and efforts taken to locate the mine or location of origin of those conflict minerals with as

4. Pursuant to Sections 13(a) or 15(d) of the Securities Exchange Act of 1934 to implement Section 1502 DFA.

5. SEC Final Rule, 2013. 
much specificity as possible. A Conflict Minerals Report should furthermore include an audit report carried out by an independent private sector auditor. This report must indicate whether the auditor finds the company's due diligence to be in conformance with the relevant due diligence framework and whether the company's description of its due diligence measures is in line with reality.

The Rule, which was issued by the SEC in August 2012, has already taken effect. As a result, companies are under an obligation to comply starting 1 January 2013, meaning that the first reports over 2013 are to be filed by 31 May 2014. It nonetheless allows for a two-year transition period. During that period, companies may deem their products 'DRC conflict undeterminable' ${ }^{6}$ if (a) they are aware that they use potential conflict minerals that originate from the Covered Countries but are unable to determine whether those minerals financed armed groups or (b) they have carried out due diligence but cannot determine for certain whether the minerals in question have originated from the Covered Countries, whether those minerals have financed or benefited armed groups or whether they are possibly not derived from recycled or scrap materials.

Although the administrative and economic burden of compliance with the DFA is a heavy one (as shall be discussed in further detail in Section 3), there is no 'deminimis exemption' for companies that only use small amounts of conflict minerals. Even if a company only uses one gram of gold per annum in its products, it must comply with section 1502 DFA.

As has been mentioned before, the primary goal of Section $1502 \mathrm{DFA}$ is to promote transparency in respect of the use of conflict minerals in supply chains of companies. The sanction on non-compliance with Section 1502 DFA therefore is also tied in with transparency: if companies file untruthful information with the SEC, they may be held liable under Section 18 of the Securities and Exchange Act for false and misleading statements. There are no 'harder' sanctions in respect of Section 1502 DFA. A significant non-legal sanction nonetheless remains: companies can be subject to naming-and-shaming by non-governmental organizations, which would harm their public image. Companies have raised this fear in the legal challenge of the Rule, as will be discussed in the section below.

\section{Criticism and Legal Challenge of the Rule}

Despite the (further) guidance offered by the SEC in the Rule, many uncertainties remain for companies. The most important question is under what circumstances a company may be said to meet the criteria posed by the Rule. When, for instance, is a country of origin search

6. Ibid., p. 29 'reasonable'? And when is material 'necessary to the functionality or production' of a product, as described in Section 2 above? If materials are inadvertently used, or if alternatives to the conflict mineral used exist, is the conflict mineral then substantial to the functionality? Is something necessary to the functionality if the conflict mineral has been intentionally added? Does it matter that the primary purpose of the product is ornamentation or decoration? ${ }^{7}$

Furthermore, the Rule also applies to companies that do not manufacture themselves, but rather contract to manufacture. The SEC has stated that a company does not 'contract to manufacture' if it only specifies or negotiates contractual terms with a manufacturer that do not directly relate to the manufacture of the product, such as training or technical support, price, insurance, indemnity, intellectual property rights, dispute resolution or other like terms or conditions. The criterion also does not apply to companies that simply affix their brand, marks, logo or label to a generic product manufactured by a third party or that service, maintain or repair a product manufactured by a third party.

Yet much room for interpretation remains. Whether a company's manufacturing falls within the scope of Section 1502 DFA all depends on the degree of control a company has over the production process: the materials, parts and components that make use of conflict minerals and that are to be used in the production process. In practice, it will not always be possible to indicate in advance whether a company must comply with the DFA or not. The SEC indicates that it has chosen not to define 'contract to manufacture' in further detail in order to mitigate costs by 'letting issuers determine based on their own facts and circumstances which of their products have conflict minerals that may trigger a reporting obligation'. ${ }^{8}$ However, it could be argued that the companies concerned would rather have more guidance in order to determine whether they need to comply with the DFA.

More importantly, the administrative burden posed by the Rule is great. When the final Rule was released, the SEC estimated the cost of compliance to be USD 3 billion to USD 4 billion. The annual cost of on-going compliance was estimated at USD 207 million to USD 609 million. ${ }^{9}$ Considering these costs for American (and international) manufacturers, it is no surprise that the Rule was met with criticism.

Not only are the costs of implementation of the Rule high, the task of mapping one's supply chain is onerous. Dutch electronics company Philips is among a few to have mapped its entire supply chain. Not surprising, if one realizes that Philips makes use of approximately 40,000 (product and service) suppliers in total. ${ }^{10}$ When distributors are used alongside subsidiary companies, the supply chain is even less transparent. It is not sur-

Ernst \& Young presentation 2013.

SEC Final Rule, 2013, p. 280

Ibid.

10. Philips annual report 2012 
prising therefore, that many companies focus only on certain high-risk suppliers or on areas where their impact is greatest.

Many of the abovementioned points were therefore raised on 19 October 2012, when a lawsuit requesting review of the Rule was filed with the District Court for the District of Columbia. Petitioners were the US Chamber of Commerce, the National Association of Manufacturers (including, inter alia, General Electric and Intel), and the Business Roundtable (which includes CEOs of companies such as Microsoft and Chevron). The Rule was challenged under the Federal Rules of Appellate Procedure, which regulates the manner in which federal administrative agencies in the United States propose and establish regulations. ${ }^{11}$

Their arguments include, in short, the following. ${ }^{12}$ First of all, they argued that the economic analysis carried out by the SEC was inadequate. In other words, the Rule, which is one of the costliest in SEC history, ${ }^{13}$ would be too expensive in practice. This argument is supported, inter alia, by research of Griffin, Lont and Sun. ${ }^{14}$ They believe the costs of implementation to be exponentially higher than the SEC estimate. Their conservative estimate amounts to 8 billion USD (in comparison with the SEC's initial estimate of 71 million USD - an 11.000 percent discrepancy - and later estimate of 3-4 billion USD). The SEC's methodology for calculating costs of the Rule has also been criticized by government officials: the office of inspector general critiqued that it was 'lacking a macro-approach'. ${ }^{15}$

Another point of criticism is that there is no exemption available for those whose use of conflict minerals is incidental or negligible (the 'de-minimis' exception described in Section 2 of this article). As a result, the burden falls heavily on small companies, who must meet the same requirements as bigger companies. Thus, the requirements posed by the DFA are steep but manageable for larger companies with a well-developed CSR policy but may be disproportionately heavy for smaller companies.

Furthermore, they argue that the SEC should not have extended application of the rule to companies that 'contract to manufacture' (as opposed to manufacture) products. They argue that the SEC could have exercised its discretion in this decision and furthermore that this decision is contrary to the plain text of the statute, since Section 1502 states that it applies to companies that 'manufacture' products; as a result of which, they argue, it should only apply to manufacturers.

Finally, and from a transparency point of view, perhaps most interestingly, petitioners argued that the disclosure

11. Pursuant to Section 15(a) Federal Rules of Appellate Procedure, federal courts may directly review or set aside decisions by federal administrative agencies such as the SEC.

12. See Opening Brief of Petitioners 2013.

13. See Ibid., p. 23

14. Griffin et al. 2012.

15. Office of Inspector General, (2012), Follow-up review of cost-benefit analyses in selected SEC rulemakings, Report No. 499, 27 January, available at: http://www.secoig.gov/Reports/AuditsInspections/ 2012/499.pdf (last accessed 18 April 2013). requirements that the Rule imposed (i.e. providing certain information publicly through annual reports and corporate websites) would violate the First Amendment of the US Constitution, which protects the right 'to speak and $[\ldots]$ to refrain from speaking'. Plaintiffs argue that having to provide a 'warning' that certain of their products are not 'DRC conflict free' (even when the origin of the minerals used would just be uncertain rather than certifiably from the DRC) would amount to compel 'burdensome and stigmatizing' speech in violation of the First Amendment, as it would force a company to associate itself publicly with groups engaged in human rights violations. This would stigmatize the company and harm its business. ${ }^{16}$ Such a 'warning' would have to meet the strict criteria set out in Zauderer $v$. Office of Disciplinary Counsel of Supreme Court of Ohio, 471 U.S. 626 (1985), plaintiffs believe. In other words, plaintiffs wanted to be free to decide whether they would like to provide certain information on conflict minerals to the public because they feared it would damage their public image.

\section{Court Verdict of 23 July 2013}

On 23 July 2013, the District Court upheld the conflict minerals Rule issued by the SEC. In short, the District Court did not agree with plaintiffs that the SEC's analysis in respect of costs and benefits of the rule was insufficient.

The Court held that the cost-benefit analysis carried out by the SEC was built upon a reasonable basis and that the relevant commission had taken into account estimates provided by various commentators and exercised appropriate discretion in coming to its conclusion. In drafting the Rule, the SEC had moreover argued that it was not up to them to determine the humanitarian benefits of the rule. Whilst plaintiffs did not agree with this point of view, the Court stated:

The SEC rightly maintains that its role was not to 'second-guess' Congress's judgment as to the benefits of disclosure, but to, instead, promulgate a rule that would promote the benefits Congress identified and that would hew closely to that demand.

Moreover, petitioners had disputed the SEC's decision not to make a de-minimis exception. The court concurred with the SEC when it argued that while it had the discretion not to create a de-minimis exception, it used its discretion to decide not to exercise the authority it had. The SEC had indicated that the creation of such an acceptance would undermine the intended impact of the rule (since conflict minerals are especially frequently

16. Opening Brief of Petitioners 2013, p. 52. See the opening brief for further substantiation of this claim and the requirements such a restriction in freedom of speech would have to meet in order for it to be valid. 
used in very small quantities). The Court noted that the SEC, in its adopting release of the Rule, had provided both policy-based and practical reasons for not adopting a de-minimis exception.

In respect of the challenge of the SEC's decision to apply the rule to companies that contract to manufacture products, the Court held that this decision was 'an amply reasonable construction of Section 1502'. The Court stated that in doing so, the SEC 'emphasized its focus on the degree of influence and control that [a company] exercises over the manufacturing process, effectively excluding "pure retailers" from the scope of the rule'. ${ }^{17}$

In respect of the First Amendment challenge posed by the petitioners, the Court held that due to the foreign relations context of the rule, Congress should be afforded considerable deference in making the 'informed judgment' that the required disclosures advance the goal of promoting peace and security in the DRC. Moreover, the Court ruled that

[A]ll that Section 1502 and the Final Rule require is that companies publish copies of their Form SD's (forms to be filed with the SEC, ALV) and/or Conflict Minerals Reports - i.e., verbatim copies of disclosures already prepared for and filed with the Commission - on their websites. Neither Section 1502, nor the Final Rule requires companies to separately or conspicuously publish on their website a list of products that have not been found to be 'DRC conflict free', as Plaintiffs intimate, nor must companies physically label their products as such on the packaging itself. ${ }^{18}$

Petitioners (including the National Association of Manufacturers) have currently filed a notice of intent that they will appeal against the District Court's ruling.

In the meantime, although just under 200 companies already made efforts to comply with the Rule in their annual reports in 2012, as much as 35 percent of 134 companies surveyed by KPMG indicated that they had not even started with compliance with the Rule yet. ${ }^{19}$

\section{Other Transparency Legislation in Place?}

The DFA is not the only Act of legislation that imposes obligations on companies to provide transparency in respect of their supply chains. The State of California has so far proven to be the most ambitious American state in this respect. It has two relevant acts in place: California SB 861, which prohibits publicly traded companies not complying with the DFA from obtaining procurement contracts through the California Department

17. District Court for the District of Columbia 2013, p. 46.

18. Ibid., p. 5.

19. KPMG Presentation 2013. of General Services until they are compliant, and the Transparency in Supply Chains Act (TSCA), which requires companies to disclose their efforts taken to eliminate human trafficking and slavery from supply chains.

\subsection{California Senate Bill 861}

Following Senate Bill 861, which was passed on 9 October 2011, which adds a section to the Public Contract Code, the state government of California is prohibited from contracting with companies that fail to comply with Section 1502 DFA. As stated in Californian Senator Corbett's press release, 'California spends $\$ 8.9$ billion annually in state contracts. The legislation is supported by 28 US investment firms with assets totalling $\$ 130$ billion.' This means that companies wanting to contract with the state that has the eighth largest economy in the world ${ }^{20}$ must meet the requirements Section 1502 DFA poses. Quite a challenge, considering the many American companies needing to comply with Section 1502 DFA had indicated they had not even started the compliance process yet.

\subsection{California Transparency in Supply Chains Act}

The California Transparency in Supply Chains Act (CTSCA), effective 1 January 2012, has as its goal to increase transparency for consumers in respect of products tainted with human trafficking and slavery, thereby encouraging them to purchase responsibly, improving the lives of victims of human trafficking and slavery.

The CTSCA applies to retail sellers and manufacturers doing business in the State of California, that have a gross revenue of over USD 100 million in annual worldwide gross receipts. Each year, the Franchise Tax Board makes a list of these companies available to the Attorney General. It therefore covers only companies that offer tangible products for sale within the State of California, not service providers.

If companies fall within the scope of this Act, they must disclose the company's efforts to eradicate slavery and human trafficking from its direct supply chain for tangible goods offered for sale. Specifically, and at a minimum, companies are to disclose on their website, with a conspicuous and easily understood link on their homepage, what they do in respect of each of the following.

First of all, they must state whether they engage in verification of product supply chains to evaluate and address risks of human trafficking and slavery. Companies must specify whether their verification was not conducted by a third party. Secondly, they must indicate whether they conduct audits of suppliers to evaluate supplier compliance with company standards for trafficking and slavery in supply chains. This disclosure must specify if the verification was not an independent, unannounced audit. Thirdly, following the CTSCA, companies must clarify whether they require that direct suppliers certify that materials incorporated into the 
product comply with the laws regarding slavery and human trafficking of the country or countries in which they are doing business. Fourthly, companies must announce to what extent they maintain internal accountability standards and procedures for employees or contractors failing to meet company standards regarding slavery and trafficking. Finally, a company must indicate if it provides relevant company employees and management with training on human trafficking and slavery, particularly with respect to mitigating risks within the supply chains of products.

Similar to Sections 1502 and 1504 of the DFA, therefore, companies are not required to solve any problems they encounter in respect of human trafficking and slavery; they are only required to provide transparency on such issues.

If companies do not meet the transparency requirements set out in the CTSCA, the Attorney General may bring an action for injunctive relief. At the moment, no such action has been brought yet by the Attorney General. Nonetheless, the Act expressly states that nothing in the section shall limit the remedies available for a violation of any other state or federal law. Alternative legal actions (such as a consumer's claim for misleading advertising statements) therefore remain possible.

The CTSCA therefore is somewhat similar in scope and requirements to Section 1502 DFA. On the basis of the research $^{21} \mathrm{I}$ carried out among companies based in the State of California, most companies currently include a statement to this extent on their websites. However, the wording in some of these statements is so broad and vague that one could doubt it would, in fact, provide any real insight into the measures a company takes to prevent human trafficking or slavery in connection to the products it retails.

\section{Private Alternatives to Legislation}

\subsection{Private Regulation}

Many sectors already have initiatives of private regulation in place that seek to accomplish these same goals. One example is the EICC Conflict-Free Smelter Programme, initiated by the Electronics Industry Citizenship Coalition and the Global eSustainability Initiative. Their combined goal is to launch a conflict-free smelter program, which identifies smelters that are certifiably conflict-mineral free (through an independent thirdparty assessment). Such initiatives combine the knowledge existing in certain industries (such as the electronics industry) in order to provide more transparency and make compliance with Section 1502 DFA easier.

21. PhD-research carried out in respect of corporate social responsibility in the supply chains of multinational companies: on contracts, codes of conduct and liability; research carried out as visiting researcher at UCLA School of Law between May and September 2013. See, inter alia, Vytopil 2012

\subsection{Codes of Conduct}

Besides industry-wide initiatives, many larger companies (including those that use the relevant minerals) already take measures to express their responsibility regarding their supply chain, for instance, by adopting a code of conduct or connecting with non-governmental initiative. One code frequently used in the electronics industry (which uses conflict minerals) is that of the aforementioned Electronics Industry Citizenship Coalition (which has also adopted conflict-mineral-specific programs ${ }^{22}$ ). The use of CSR codes of conduct (either company-owned or based on other initiatives) is now more prevalent than ever: a comprehensive study reported in 2007 that 72 percent of multinational companies based in England had a CSR code in place. ${ }^{23}$ These codes can provide greater insight into the way companies perceive their role with regard to their stakeholders, by setting out rights and obligations of all stakeholders. But besides providing transparency, these codes may also have legal consequences, for instance, if they are binding upon the multinational and/or its supply partner. The question of bindingness is especially relevant when investigating if these codes could fulfil the aims of the DFA; if codes are not legally binding, the need to adopt additional (binding, public) legislation in respect of conflict minerals could be greater.

\section{Qualification Codes of Conduct in Practice}

In most legal systems, the consensus is that codes of conduct are voluntary and not binding upon the multinational that adopts it. In the Netherlands, for instance, it has been argued that voluntarily drafted or accepted codes are not legally binding for those that adhere to it. ${ }^{24}$ In England, this theme has not yet been explored, but the same general theory would hold: codes of conduct are not binding for the multinational per se. After all, in English law, 'informal gratuitous promises' are not legally binding. Such a promise only becomes legally binding upon the promisor when it is in a deed. ${ }^{25}$ However, to my knowledge companies never shape a code of conduct in the form of a deed; I have never encountered it in the process of my research. ${ }^{26}$ Generally speaking, therefore, a code of conduct adopted by an English multinational company that has simply been

22. See the Conflict-Free Smelter Program of the EICC, and the OECD Due Diligence Guidance for Responsible Supply Chains of Minerals from Conflict-Affected and High-Risk Areas.

23. Edwards et al. 2007.

24. Koelemeijer 2005, p. 108. For further exploration of this theme in respect of the Netherlands, see also: Vytopil 2012.

25. And it meets all the requirements for a deed; see Treitel 2010.

26. This research analyses various instruments through which companies try to gain contractual control. It investigates contracts and codes of conduct used by multinational companies in the Netherlands, England and the United States and assesses how these various modes impact the potential liability of multinational companies for human rights violations occurring in their supply chains. 
posted on its website without incorporation in any contract will not be legally binding for the multinational or for its supply partners. At the same time, this does not mean that such codes are without value in terms of private law and that they cannot provide a valuable contribution to the legal and semi-legal frameworks in which multinationals function. The adoption of a CSR code may play a role in the establishment of a company's responsibility and (legal) liability in case of CSR violations. $^{27}$

Moreover, codes of conduct are frequently used in relationships between multinationals and their suppliers, ${ }^{28}$ and they can become binding if multinationals so wish. What requirements must such codes of conduct meet in order for them to be binding for the multinational and its suppliers? It is possible to distinguish between the situation that a code is used independently of other possible contracts with a supplier and the situation in which a code is an annex to another contract.

In the first case, the code itself must meet the general requirements for contracts in order to become binding upon the multinational company and its supply partner. ${ }^{29}$ In English law, required are offer and acceptance, the intention of parties to be legally bound by the terms of the code of conduct, and consideration. Of these, consideration and the intention to create legal relations could be problematic. Consideration entails that each party must offer something in return for the other party's promise, either a detriment to the promisee (giving value) or benefit to the promisor (receiving value). In order to meet this criterion, the code must be viewed from a perspective of a broader supply relationship. Only then does the multinational, too, provide consideration, which consists of allowing the supplier to enter into a business relationship with him. Furthermore, if companies are not careful in drafting their CSR policy, the requirement of the intention to create legal relations could also be problematic. Whilst English law assumes that commercial parties have the intention to create legal relations, the code may consist of wording that is so vague and aspirational that it conveys not to have the intention to create legal relations. In short, when viewed in conjunction with the contractual relationship between multinational and supplier, a code may be seen as binding, as long as the (wording of the) code conveys an intention to create legal relations.

An alternative is that a code is not used as stand-alone document, but used in conjunction with another contract. In such a case, the code of conduct could qualify as a term to the general contract. English law requires in

27. Especially when part of contractual relations, this may impact liability: Furmston 2012, p. 239.

28. Vytopil 2012, pp. 155-169.

29. In respect of the Netherlands, the legal qualification of the use of codes of conduct in supply chains has been described, see: Vytopil 2012. In respect of the legal systems in England and the United States (both countries in which the use of codes of conduct is prevalent), this phenomenon has not yet been investigated by legal scholars; hence the focus on English law in this article. Forthcoming work will focus on the use and legal qualification of codes of conduct in American supply chains. respect of such terms that the document is either signed by the supplier or that the multinational company gives reasonable notice of the code, which must have been given before the contract is concluded ${ }^{30}$ Finally, a code can also become binding between multinational and supplier if the same document is used regularly in the course of dealing between parties. ${ }^{31}$ In such a case, it is generally accepted that these terms apply to future transactions unless expressly indicated otherwise. It is not necessary that parties have read the terms used or even that the main contract is in writing. ${ }^{32}$

\section{A Continental Alternative?}

All in all, companies are making efforts to increase their transparency in respect of their supply chains in general and conflict minerals in particular. It is nonetheless imaginable that lobbying could lead to adoption of legislation comparable to Section 1502 DFA, either in just the Netherlands or in the whole of Europe.

It has been argued that a European initiative would be preferable to a national one, since it would level the playing field for all European countries. ${ }^{33}$ At the moment, there is no concrete draft proposal for a guideline or other legislation in respect of conflict minerals. ${ }^{34}$ Between March and July of 2013, the European Commission ran a process of public consultation regarding a comparable EU initiative in respect of 'responsible sourcing of minerals from conflict-affected and highrisk areas'. The Commission will use this process in order to help it decide whether the public and private initiatives in respect of mineral mining already in place should be complemented and/or continued. ${ }^{35}$ In its consultation process, the European Commission, inter alia, asked for an analysis of advantages and disadvantages of Section 1502 DFA in order to learn from it. ${ }^{36}$

The European Commission has nonetheless made clear it does not intend to mimic the DFA, ${ }^{37}$ although it would be wise to prevent a situation in which multinational companies must comply with two sets of conflicting regulation, especially for those companies that fall

30. Furmston 2012, p. 208.

31. Spurling v. Bradshaw [1956] 2 All ER 121, [1956] 1 WLR 461.

32. Henry Kendall \& Sons v. William Lillico \& Sons [1969] 2 AC 31.

33. Van der Heijden 2012

34. The proposal for a European Transparency Guideline does contain rules regarding payments to foreign governments but none that relate only to conflict minerals.

35. At the date of submission of this article, no conclusions had been announced yet by the European Commission.

36. Question 2.7 of the questionnaire of the Public Consultation on a Possible EU Initiative on Responsible Sourcing of Minerals Originating from Conflict-Affected and High-Risk Areas, European Commission, now closed but it can still be found online, at: <www.komora.cz/down load.aspx?dontparse=true\&FileID=10720>, last accessed on 5 September 2013.

37. The European Commission for instance is considering an exemption for Small and Medium Enterprises; see Question 3.4 of the questionnaire of the Public Consultation on a Possible EU Initiative on Responsible Sourcing of Minerals Originating from Conflict-Affected and High-Risk Areas, supra. 
under both European legislation and within the scope of the DFA. With the deadline for public consultation now having passed, the European Commission will be collecting the input from the public to draft a new strategy in respect of conflict minerals; the future of conflict minerals legislation in the European Union therefore remains unknown at the moment.

\section{Conclusions}

This article has described the requirements companies must meet in order to fulfil the requirements of Section 1502 DFA and the accompanying SEC Rule. Moreover, it has discussed the societal criticism and ruling of the District Court for the District of Columbia in respect of the Rule. After all, the burden of a legal initiative comparable to Section 1502 DFA is a heavy one, from both a practical and an economic point of view. In investigating whether similar legislation should be adopted in the Netherlands or Europe, it would be wise for the European Commission to also take into account to what extent private initiatives are capable of meeting the goals that the DFA has set.

Because whilst not automatically the case, supply chain codes used by companies could provide similar transparency and may become contractually binding upon the parties that use them. Codes may also play an additional role in the liability of multinationals in case of CSR violations. Since the use of codes of conduct is increasingly widespread, such a private initiative may offer a solution that is less burdensome to companies. Although the goals of the DFA are noble, there are many hurdles to overcome before successful implementation will be possible, in either the United States or the European Union.

\section{Bibliography}

\section{Publications}

The Economist, Comparing US States with Countries, Stateside Substitutes, 13 January 2011, The Economist Online, available at: http://www.economist.com/blogs/dailychart/2011/01/ us_equivalents, last accessed 4 September 2013.

T. Edwards et al., "Corporate Social Responsibility in Multinational Companies: Management Initiatives or Negotiated Agreements?", February 2007, International Institute for Labour Studies Discussion Paper Series, Geneva, International Institute for Labour Studies.

M.P. Furmston, Cheshire, Fifoot and Furmston's Law of Contract, Oxford, Oxford University Press, 2012.

P. A. Griffin, D. H. Lont and Y. Sun, "Supply Chain Sustainability: Evidence on Conflict Minerals", 14 August 2012, Working Paper Series, available at SSRN: http://ssrn.com/ abstract $=2129371$, last accessed 18 April 2013 .

M.J. van der Heijden, “The Dodd-Frank Act's Interventionist Approach to Business and Human Rights", TvOB, 2012-5.

M. Koelemeijer, in J. Hamers \& C. Schwarz, Noodzaak, plicht of menselijkheid van Maatschappelijk Verantwoord Ondernemen: een multidisciplinaire verkenning, Den Haag, Boom Juridische uitgevers, 2005.

G.H. Treitel The Law of Contract, London, Sweet \& Maxwell, 2010.

A.L. Vytopil, "Contractual Control and Labour-Related CSR Norms in the Supply Chain: Dutch Best Practices", 1 Utrecht Law Reviem, 2012, pp. 155-169.

\section{Websites}

District Court for the District of Columbia, Memorandum Opinion Denying Plaintiffs Motion for Summary Fudgment, Civil Action No. 13-cv-635 (RLW), 23 July, p. 46, available at: <http:// www.srz.com/files/upload/Conflict_Minerals_Resource_ Center/NAM_vs_SEC_Memorandum_Opinion_Denying_Pl aintiffs_Motion_for_Summary_Judgment.pdf $>$, last accessed on 4 September 2013.

Ernst \& Young presentation, Conflict Minerals: What You Need to Know about the Nem Disclosure and Reporting Requirements and How Ernst ES Young can help, available at <http:// www.ey.com/Publication/vwLUAssets/Conflict_minerals/ \$FILE/Conflict_Minerals_US.pdf>, last accessed on 4 September 2013.

KPMG Presentation, Dodd Frank Act Conflict Minerals (Section 1502), May 2013, available at: <http://www.kpmg.com/US/ en/IssuesAndInsights/ArticlesPublications/Documents/con flict-minerals-overview-deck-2013.pdf >, last accessed on 2 September 2013

Philips Annual Report 2012, available at: <http://www.annualreport2012.philips.com/annual_report_2012/en/sustainabili ty_statements/supplier_indicators.aspx $>$, last accessed on 18 April 2013.

Office of Inspector General, Follow-up Reviem of Cost-Benefit Analyses in Selected SEC Rulemakings, Report No. 499, 27 January 2012, available at: <http://www.secoig.gov/Reports/ AuditsInspections/2012/499.pdf $>$, last accessed 18 April 2013.

Opening Brief of Petitioners, filed on 16 January 2013, available at: <http://www.nam.org/ /media/B5825277D7C144A48C 2C4442054900D4/NAM_v_SEC_brief_only_01162013.pdf>, last accessed on 4 September 2013.

SEC Final Rule adopted pursuant to Section 1502 DFA, Release No. 34-67716; File No. S7-40-10, available at: <http:// www.sec.gov/rules/final/2012/34-67716.pdf>, p. 206, last accessed on 4 September 2013. 